\title{
The Influence of Financial Inclusion on MSMEs' Performance Through Financial Intermediation and Access to Capital
}

\author{
Kusuma RATNAWATI ${ }^{1}$
}

Received: August 01, 2020 Revised: September 20, 2020 Accepted: October 05, 2020

\begin{abstract}
This study aims to analyze the influence of financial inclusion on micro-, small-, and medium-sized enterprises' (MSMEs) performance and examine the mediation role of financial intermediation and access to capital. The object of this study is MSMEs in Malang, Indonesia. The sample consists of 100 MSME actors in Malang City, which is determined using Roscoes theory. The data is collected using Simple Random Sampling method, by distributing questionnaire measured with Likert scales. The hypotheses proposed in this study are examined using Partial Least Square (PLS) model. The results of this study show that financial inclusion influences MSMEs' performance both directly and indirectly through mediation from financial intermediation and access to capital. The direct influence means that the efforts to increase access to financial services, especially access to credit financing for MSMEs, will be able to increase market share, number of workers, sales, as well as profit of the MSMEs. Increased financial inclusion has a major impact on improving MSMEs' performance through financial intermediation compared to access to capital. This means that the increase of financial access for MSMEs followed by an increase in financial intermediation in the form of a financial service approach to MSMEs will improve MSMEs' performance.
\end{abstract}

Keywords: Financial Inclusion, MSMEs' Performance, Financial Intermediation, Access to Capital

JEL Classification Code: G21, G2, M0

\section{Introduction}

The concept of financial inclusion has become a major issue on the development agenda in a number of developing countries, including Indonesia. According to the United Nations, financial inclusion refers to easy access to financial services for low-income people and micro-, small-, and medium-sized enterprises (MSMEs). The Word Bank (2014), shows that more than 3 billion people in the world still lack access to and use of basic financial services, with the majority of this number residing in developing countries, such as Indonesia.

\footnotetext{
${ }^{1}$ First Author and Corresponding Author. Department of Management, Faculty of Economics and Business, Universitas Brawijaya, Malang, Indonesia [Postal Address: Jl. Veteran, Ketawanggede, Kec. Lowokwaru, Kota Malang, Jawa Timur 65145, Indonesia] Email: kusuma@ub.ac.id

(C) Copyright: The Author(s)

This is an Open Access article distributed under the terms of the Creative Commons Attribution Non-Commercial License (https://creativecommons.org/licenses/by-nc/4.0/) which permits unrestricted non-commercial use, distribution, and reproduction in any medium, provided the original work is properly cited.
}

The government of Indonesia implements the National Strategy for Financial Inclusion to increase access, use, and availability of the formal financial system for all levels of society, especially MSMEs. This is because MSMEs are a vital sector for the Indonesian economy (Zain, 2010), as the number of MSMEs in Indonesia reaches $99.99 \%$ of the total business actors (Ministry of Cooperatives and MSMEs of Indonesia, 2017). According to Irawati (2016), MSMEs contribute greatly to the nations economic growth through employment, foreign exchange savings, and poverty alleviation. OJK (2016) reported that statistically, MSMEs contribute $57.9 \%$ of Indonesia's GDP and absorb $97 \%$ of national workers. A survey conducted by the Organization for Economic Co-operation and Development (2018) stated that 70.3\% of Indonesian people work in MSMEs.

Financial inclusion is urgently needed for the MSME sector, because it provides the widest possible access and eliminates barriers to financial services (Herispon, 2017). According to Krishna (2016), financial inclusion enhances the role of existing financial institution and increases the reach of larger and faster financial services. Fahmy et al. (2016) stated that financial inclusion is very influential 
on MSMEs because it is able to help overcome financial problems faced by MSMEs.

Previous studies by Abdmoulah and Jelili (2013), Chauvet and Jacolin (2017), Lee et al. (2019), Khan (2011), and Morgan and Pontines (2014) have examined the impact of financial inclusion on growth. The results from Abdmoulah and Jelili (2013), Chauvet and Jacolin (2017) and Lee et al. (2019) showed that financial inclusion significantly and positively influences company growth and performance. According to Khan (2011) and Morgan and Pontines (2014), financial inclusion reduces liquidity barriers and encourages investment, thereby increasing output and employment opportunities. Proper implementation financial inclusion can increase the economic activities of MSMEs (Egbetunde, 2012; Martinez, 2011; Mbotor \& Uba, 2013; Okafor, 2012; Onaolapo, 2015; Yaron et al., 2013).

However, recent studies conducted by Ejiofor et al., (2020) as well as Awoyemi et al. (2015) explicitly concluded that financial inclusion has no influence on MSMEs' growth. This shows the inconsistency of findings related to the influence of financial inclusion on MSMEs' performance. On the other hand, some researchers concluded that financial inclusion influences financial intermediation, and several studies prove that financial intermediation influences MSMEs' performance. Prasad (2010) stated that financial inclusion can increase efficiency in financial intermediation by increasing domestic saving and investment. Mishkin (2007) concluded that financial intermediation through the opening of many bank branches and the entry of new financial service providers on financial market can pave the way for the provision of a variety of financial products and services in accordance with the needs of MSMEs. Fafchamps and Schündeln (2013) found that there is a significant relationship between financial intermediation and MSMEs' growth. Therefore, financial inclusion can influence MSMEs' performance through increased financial intermediation, but the role of financial intermediation itself has not been studied.

Other researchers also examined the influence of financial inclusion on the increase of access to capital. Okafor (2012) and Nurjannah (2017) proved that financial inclusion can accelerate the credit flow to MSMEs. Meanwhile, Donati (2016) examined the influence of access to capital on MSMEs' performance, and concluded that MSMEs without access to affordable credit would experience difficulties in improving their performance and expanding their business. These findings indicate that financial inclusion can increase MSMEs' access to capital, which will affect MSMEs' performance.

MSMEs still face access to capital problems (Beck et al., 2004). Banerjee \& Duflo (2014) and Muhajir (2015) proved that MSMEs have difficulty in obtaining loans from formal financial institutions. The problems start from distance (Shankar, 2013), social, and personal problems that have the potential to become the main barrier to financial access for the community (Cnaan et al., 2012). According to Rifai (2017), it is difficult for MSMEs to access capital from formal financial institution because their business backgrounds can be categorized as unbankable. The strength of capital will increase MSMEs' growth and the output produced, thus MSMEs can expand their business and encourage job creation (Sohilauw, 2018; Haltiwanger, 2013; Yudaruddin, 2020).

Access to financing sources is very important for company survival and performance through adequate funds for working capital, fixed asset investment, placement of skilled workers, and market development (GPFI, 2013). Primus (2015) emphasized that MSMEs have big potential, so that there is a need for capital support and guidance to pursue opportunities for MSMEs' growth performance (Ahmad \& Arif, 2015). In order to increase access to capital for MSMEs, Bank Indonesia has issued Bank Indonesia Regulation (PBI) Number 14/22/PBI/2012 dated December 21, 2012, regarding Lending by Commercial Banks and Technical Assistance for MSMEs Development. Even in 2018, the ratio of credit to MSMEs was set at the lowest $(20 \%)$ of total loans disbursed. This is aimed to improve the MSME sector. MSME in Malang City is a big potential sector that shows a rapid development in the last three years. In 2016, there were only 1,970 MSMEs in Malang City. It increases to 3,292 in 2017 and 3,711 MSMEs in 2018. Therefore, the author uses MSMEs in Malang as the research object in this study.

This study aims to examine the influence of financial inclusion on MSMEs' performance and examine the mediation role of financial intermediation and access to capital. This study is different from the previous studies, as the researcher uses variables to fill the research gap. This study also uses more complex indicators to measure MSMEs' performance than the previous studies. Abdmoulah and Jelili (2013), Chauvet and Jacolin (2017), and Lee et al. (2019) only uses sales growth indicator, while this study uses four indicators, namely, sales growth, profit growth, workforce growth, and market share growth.

\section{Literature Review}

\subsection{MSMEs' Performance}

According to King and Zeithaml (2001), firm performance is a function of how well managers build their organizations around the limitations of existing resources, or a function of corporate governance mechanisms (Calantone et al., 2002). Performance is the result of individual and group work functions in an organization affected by various factors to achieve a common goal within a specified time 
period (Tika, 2012). Sidharta et al. (2014) proved that factors that influence MSMEs' performance are internal and external factors. Wilkinson (2002) stated that MSMEs will grow and develop if there are supports from the environment and regulations. The measurement of firm performance can be seen from the achievement of goal and objective settings, the profitability and market share of the business operations, the stakeholder acceptance from organizational activities, and the executive satisfaction of the business outcomes (Joni, et al., 2019; Phornlaphatrachakorn \& Na-Kalasindhu, 2020). In addition, Rokhayati (2015) stated that MSMEs' performance can be measured through sales, capital, labor, and market share of profit growths.

\subsection{Financial Inclusion}

Financial inclusion is an economic condition in which individuals and companies access to financial services are not denied (Amidžić et al., 2014), and that the majority of individual can take advantage of the available financial services (Global Financial Development Report, 2014), and they seek to include poor households in the formal financial system (Hannig \& Jansen, 2010). This shows that financial inclusion is a process that ensures ease of access, availability, and benefits of the formal financial system for all economic actors (Sarma, 2012) and ensures that the public can access financial services as a whole (Agrawal, 2008), as well as the existence of efforts aimed at removing all forms of barriers to public access in utilizing financial services (Bank Indonesia, 2014).

In addition, financial inclusion is also an intervention strategy that seeks to overcome market friction that hinders financial markets from operating to the poor or underprivileged (Julie, 2016). This intervention aims to attract the unbanked population into the formal financial system, so that they have the opportunity to access formal financial services, promote a culture of saving, increase access to credit, and introduce efficient payment mechanisms (Chakravarty \& Pal, 2013). Policymakers are required to create effective opportunities for financial inclusion, capable of accelerating the introduction of innovative technologies, regulatory reforms, and infrastructure acquisitions that reduce transaction costs and enable faster, more efficient, and convenient delivery of financial services (Neaime \& Gaysset, 2018). However, it does not necessarily have a positive influence in all cases (Mehrotra et al., (2015).

Research regarding the influence of financial inclusion on MSMEs' growth has been done by numbers of researchers, namely, Abdmoulah and Jelili (2013), Banarjee (2014), Chauvet and Jacolin (2017), Lee et al. (2019), Khan (2011) as well as Morgan and Pontines (2018). Several studies concluded that proper implementation of financial inclusion can increase economic activity, including improving
MSMEs' performance (Egbetunde, 2012; Goodland et al., 2012; Khan, 2011; Martinez, 2011; Mbotor \& Uba, 2013; Okafor, 2012; Onaolapo, 2015; Yaron et al., 2013).

Based on these findings, the researcher assumes that financial inclusion will allow MSMEs to access more financial services at affordable costs, so it can improve MSMEs' performance. Thus, the first hypothesis that is proposed is:

H1: Financial inclusion positively and significantly influences MSMEs' performance.

\subsection{Financial Intermediation}

Financial intermediation theory was first formalized by Goldsmith (1969), Shaw (1973), and McKinnon (1973). Financial intermediation is a process in which financial institutions collect deposits and provide loan information to support investment in the economy (Gorton \& Winton, 2002), or a process of purchasing surplus funds from economic units, namely the business sector, government institutions, and individuals (households) for the purpose of providing funds for deficit economic units (Rivai, 2007; Mathews \& Thompson, 2008).

According to Mishkin, (2007), Kendall et al., (2010), and Demirguc-kunt and Klapper (2012), financial intermediation through the opening of many bank branches and the entry of new financial service providers on the financial market can pave the way for the provision of variety of financial products and services that are in line with the economic status of the lower classes, thereby increasing access to financial services (Chandan \& Mishra, 2010). Gurley and Shaw (1960), and Diamond and Dybvig (1983) stated that intermediaries such as banks can improve economic efficiency through facilitating transactions and portfolio creation, alleviating household liquidity constraints, minimizing risk spread over time, and reducing asymmetric information problems in financial markets.

Chandan and Mishra (2010); Ergungor (2006); Kempson et al., (2004); DeGennaro (2005); Mathew and Thompson (2008); Rau (2004); Nissanke and Stein, (2003); Stiglitz and Greenwald (2003); Menkhoff (2000); Mishkin (1998) have examined the relationship of financial inclusion and financial intermediation in developing countries. Based on these findings, it can be assumed that financial inclusion can enhance financial intermediation.

H2: Financial inclusion positively and significantly influences financial intermediation.

In addition, Ongore and Kusa (2013) and Chibba (2009) argued that through their intermediary function, banks play an important role in the efficient allocation of resources 
that are mobilized for productive activities. Merton and Bodie (2004) also showed that financial intermediaries are able to allocate scarce resources in uncertain environment. Banks rely on the information obtained to screen and define new clients including the poor (Rau, 2004; Nissanke \& Stein, 2003; Mishkin \& Eakins, 2009). However, due to information asymmetry and high transactional costs, financial intermediaries do not provide loans to those without collateral (Rosengard \& Prasetyantoko, 2011).

Fafchamps and Schündeln (2013) examined the influence of local financial development on company performance. They found that there is a significant relationship between local banks availability and faster growth for SMEs. Nurjannah (2017) also found that accessibility to financial institution affects MSMEs' development. Okello (2017) examined the relationship between access to finance and MSMEs' growth, and found that access to finance significantly and positively influences MSMEs' growth. Thus, it can be concluded that financial intermediation can increase MSMEs' performance, and the third hypothesis can be formulated as follows:

H3: Financial intermediation positively and significantly influences MSMEs'performance.

\subsection{Access to Capital}

Capital is one of the main factors for carrying out business activities. Sufficient capital will increase MSMEs' growth and increase the output produced, so that MSMEs can expand their business and encourage job creation (Sohilauw, 2018; Haltiwanger, 2013; Yudaruddin, 2020). According to Xuan (2020), investment capital is a condition for business to invest and develop, improve competitiveness, productivity, and efficiency. Access to capital is identified as the most important factors in determining MSMEs' growth and survival (IFC, 2010; OECD, 2006). Access to finance enables MSMEs to make productive investments to expand their businesses and to acquire the latest technologies to ensure their competitiveness, and drive innovation, macroeconomic resilience, and GDP growth (Beck \& Demirguc-Kunt, 2006). Access to capital and finance are important tools used to pursue growth opportunities for MSMEs' performance (Ahmad \& Arif, 2015).

Fahmy, et al. (2016) stated that financial inclusion can help to overcome financial problems. Banking access positively and significantly influences credit extended to the MSME sector. The more bank office networks are, the more credit will be absorbed in this sector. Based on the previous studies, it can be assumed that financial inclusion and financial intermediation can increase access to capital for MSMEs. Thus, the researcher formulated the following hypothesis:
H4: Financial inclusion positively and significantly influences access to capital.

H5: Financial intermediation positively and significantly influences access to capital.

Kevane and Wydick (2001) also stated that providing credit to MSMEs encourages economic growth through increasing business capitalization, creating job opportunities, and long-term income growth. More credit means more company formation and economic growth (Aghion \& Bolton, 1997). On the other hand, Brown et al. (2005) and Chauvet and Ehrhart (2018) found that access to external credit will substantially increase sales growth and company growth (Banarjee, 2014). Dimitrov and Tice (2006) revealed that credit constraints, either due to bad credit or a recession, can encourage companies to experience lower sales growth rates.

A study conducted by the World Bank (2013) shows that access to finance improves company performance and growth by facilitating market entry, risk reduction, promoting innovation, and entrepreneurial activity in developing countries. Based on these findings, the sixth hypothesis is formulated as follows:

H6: Access to capital positively and significantly influences MSMEs'performance.

The implementation of good financial inclusion, apart from reducing liquidity barriers and increasing financial intermediation, can improve access to credit for MSMEs, which in turn can improve MSMEs' performance. According to Okafor (2012) and Nurjannah (2017), financial inclusion can accelerate credit flow to MSMEs and support its growth. Without access to affordable credit, MSMEs will experience difficulties in expanding their business (Donati, 2016). Calcagnini et al. (2014) showed that collateral easily allows companies to access credit, especially to reduce payment costs. Lack of collateral appears to be an unfavorable characteristic for companies in developing countries.

Mishkin (2007) argued that financial intermediation through the opening of many bank branches and the entry of financial service providers in the financial market can pave the way for the provision of varieties of financial products and services that are in accordance with MSMEs' needs. It is strengthened by Chandan and Mishra (2010) that the presence of a structure financial institution such as offices, branches, and personnel resulted in increased access to financial services by MSMEs. Fafchamps and Schündeln (2013) found a significant relationship between local banks availability and faster growth for MSMEs. Therefore, financial inclusion can affect MSMEs' performance by increasing financial intermediation. Thus, the hypothesis proposed in this study is: 
H7: Financial inclusion positively and significantly influences MSMEs' performance mediated by financial intermediation.

H8: Financial intermediation positively and significantly influences MSMEs' performance mediated by access to capital.

H9: Financial inclusion positively and significantly influences MSMEs' performance mediated by financial intermediation and access to capital.

\section{Research Method}

This study is conducted in Malang City with the MSMEs located there as the research object. The population of this study is MSME actors in Malang City. The sample is determined using Roscoes theory (Saidani et al., 2013), with the results of 100 MSMEs actors from all MSMEs in Malang City. The data is collected with Simple Random Sampling method by distributing questionnaire measured using Likert scales. The data analysis technique in this study is using Multivariate analysis with Partial Least Square (PLS) model. The data is analyzed using inner model and outer model test - inner model test includes variable significance test, while outer model test is used to examine if the variable is valid and reliable.

The operational definitions of the variable and measurement dimensions for each of the variables are described in Table 1 as follows:

Table 1: Operational Definitions of Variable

\begin{tabular}{|c|c|c|c|c|}
\hline Variable & Definition & Indicator & & Item \\
\hline \multirow{10}{*}{$\begin{array}{l}\text { Financial } \\
\text { Inclusion }(X)\end{array}$} & \multirow{10}{*}{$\begin{array}{l}\text { All efforts to } \\
\text { increase access, } \\
\text { availability, and } \\
\text { benefits of the } \\
\text { formal financial } \\
\text { system for } \\
\text { all economic } \\
\text { actors. } \\
\text { (Claessan, } \\
\text { 2016; Beck } \\
\text { et al., 2008; } \\
\text { Ardic et al., } \\
\text { 2011; Okello } \\
\text { et al., 2017; } \\
\text { Bongomin et al., } \\
\text { 2018; Lee et al. } \\
\text { 2019; Klassen, } \\
\text { 2010) }\end{array}$} & \multirow{3}{*}{$\begin{array}{l}\text { Benefits for } \\
\text { well-being }\end{array}$} & $\mathrm{X} .1 .1$ & $\begin{array}{l}\text { The financial services offered by banks/cooperatives increase } \\
\text { the need for financing }\end{array}$ \\
\hline & & & $\mathrm{X} .1 .2$ & $\begin{array}{l}\text { The financial services offered by banks/cooperatives increase } \\
\text { access to financial services }\end{array}$ \\
\hline & & & X.1.3 & $\begin{array}{l}\text { The financial services offered by banks/cooperatives add to } \\
\text { the financing of employee capacity building }\end{array}$ \\
\hline & & \multirow{2}{*}{$\begin{array}{l}\text { Use of } \\
\text { storage } \\
\text { service } \\
\text { finance }\end{array}$} & X.1.4 & $\begin{array}{l}\text { Savings products provided by banks/cooperatives are } \\
\text { appropriate }\end{array}$ \\
\hline & & & X.1.5 & Savings products provided by banks/cooperatives are secure \\
\hline & & \multirow{2}{*}{$\begin{array}{l}\text { Access to } \\
\text { financial } \\
\text { financing }\end{array}$} & X.1.6 & Loan products provided by banks/cooperatives are needed \\
\hline & & & $\mathrm{X} .1 .7$ & $\begin{array}{l}\text { The terms and conditions regarding the use of loans provided } \\
\text { by banks/cooperatives are profitable }\end{array}$ \\
\hline & & \multirow{3}{*}{$\begin{array}{l}\text { Quality of } \\
\text { financial } \\
\text { services }\end{array}$} & X.1.8 & Financial services provided by banks/cooperatives are secure \\
\hline & & & X.1.9 & $\begin{array}{l}\text { The initial account opening fee charged by the banks/ } \\
\text { cooperatives is affordable }\end{array}$ \\
\hline & & & $\mathrm{X} .1 .10$ & The cost of traveling to the banks/cooperatives is affordable \\
\hline \multirow{6}{*}{$\begin{array}{l}\text { Financial } \\
\text { Intermediation } \\
\left(Z_{1}\right)\end{array}$} & \multirow{6}{*}{$\begin{array}{l}\text { A process that } \\
\text { provides a link } \\
\text { between lenders } \\
\text { and borrowers } \\
\text { (Bongomin } \\
\text { et al., 2018; } \\
\text { Dutta \& Dutta, } \\
\text { 2011; Allen et al. } \\
\text { 2011 \& Yaron et } \\
\text { al., 1997). }\end{array}$} & \multirow{6}{*}{$\begin{array}{l}\text { Market } \\
\text { penetration }\end{array}$} & Z.1.1 & $\begin{array}{l}\text { Banks/cooperatives have the idea of increasing customer } \\
\text { satisfaction }\end{array}$ \\
\hline & & & Z.1.2 & $\begin{array}{l}\text { Banks/cooperatives have a clear market segment for each } \\
\text { consumer }\end{array}$ \\
\hline & & & Z.1.3 & Banks/cooperatives strive to increase customer loyalty \\
\hline & & & Z.1.4 & $\begin{array}{l}\text { Banks/cooperatives are trying to increase the frequency and } \\
\text { volume of services }\end{array}$ \\
\hline & & & Z.1.5 & $\begin{array}{l}\text { Banks/cooperatives try to have product and price advantages } \\
\text { over competitors }\end{array}$ \\
\hline & & & Z.1.6 & $\begin{array}{l}\text { Banks/cooperatives collaborate with communities and MSMEs } \\
\text { organizations }\end{array}$ \\
\hline
\end{tabular}




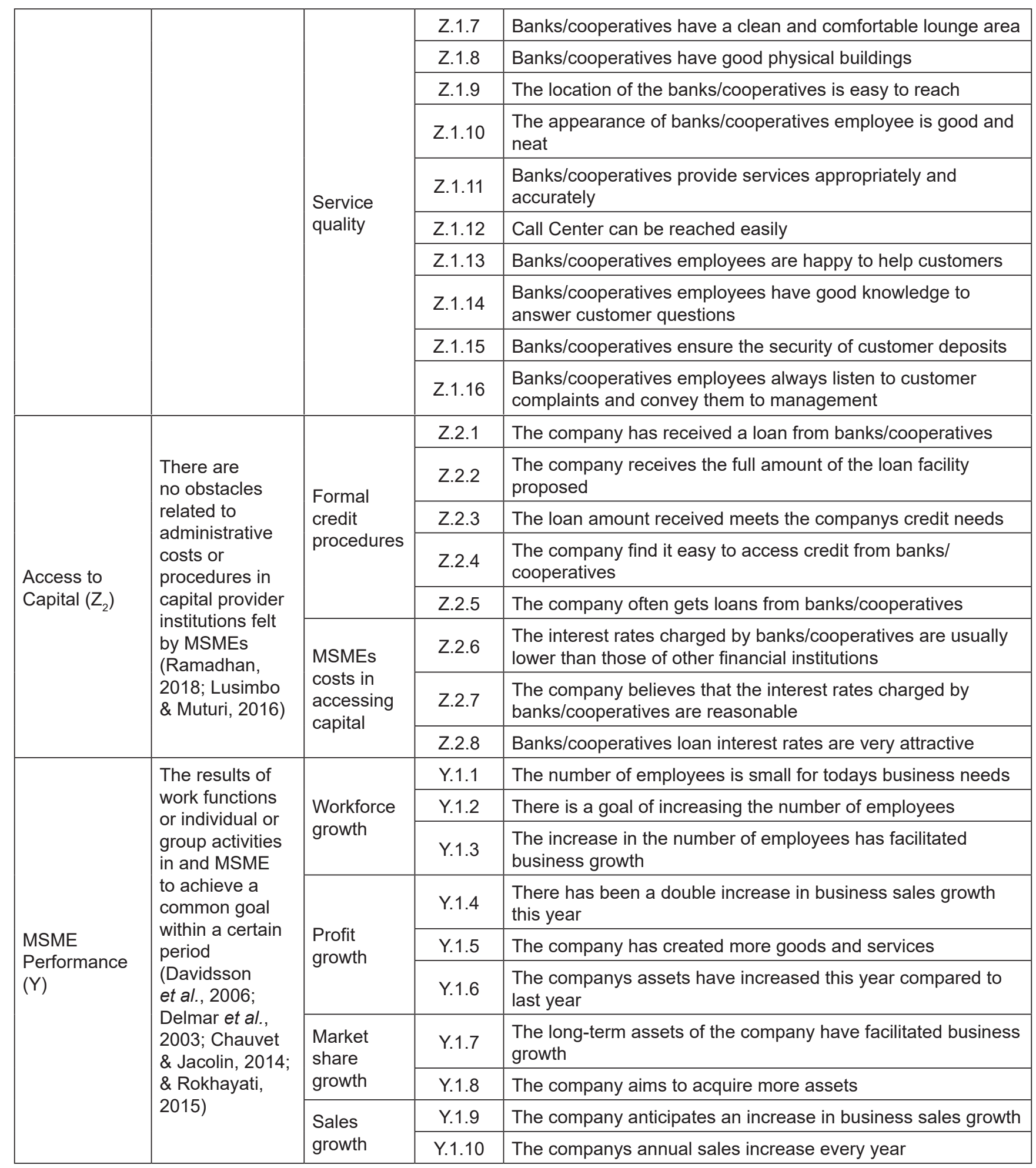


The research model of this study is presented in Figure 1:

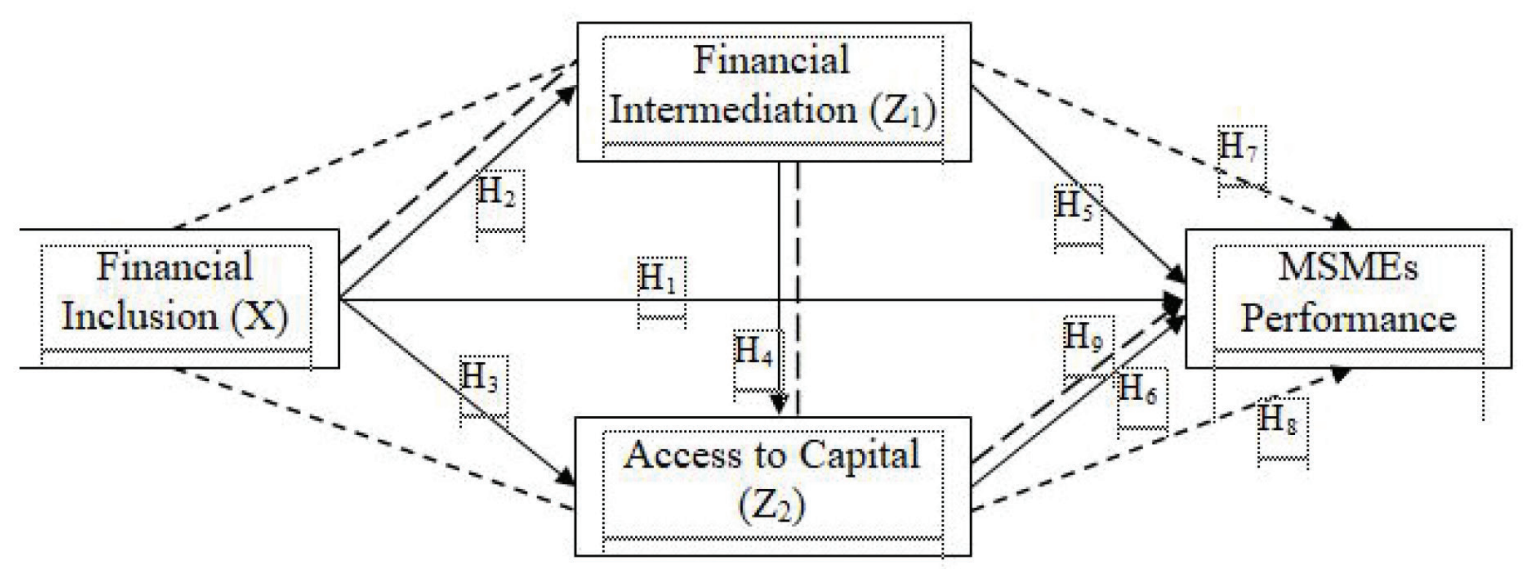

Figure 1: Research Model

\section{Research Results}

\subsection{Outer Model Test}

\subsubsection{Convergent Validity and Discriminant Validity}

Convergent validity of the measurement model with reflexive indicators can be assessed based on the correlation between the item score and the variable score. Individual indicators are considered valid if they have a correlation value above 0.70 . Based on the measurement model, it can be known the correlation value between indicator and its variables. The loading factor value of each variable can be seen in Table 2, 3, 4, and 5.

Financial inclusion $(\mathrm{X})$ variable consists of 10 questionnaire items. Based on Table 2, it can be seen that the loading factor of items X.1.9 and X.1.10 is less than 0.7, so it can be said to be invalid and must be removed from the model.

MSMEs' performance (Y) variable also consists of 10 questionnaire items. Based on Table 3, it is known that there are five items with values below 0.7, namely, Y1.1, Y1.5, Y1.6, Y1.8, and Y1.10, thus these five items must be eliminated from the model.

Financial intermediation (Z1) variable consists of 16 questionnaire items. Based on Table 4, it is known that there are five items with values below 0.7 , namely, Z.1.5, Z.1.7, Z.1.8, Z.1.9, and Z.1.12 thus these five items must be removed from the model. Access to capital variable consists of eight questionnaire items that are all valid (see Table 5).
Table 2: Loading Factor Value of Financial Inclusion (X)

\begin{tabular}{|l|c|c|c|}
\hline Indicator & Item & Loading Factor & Results \\
\hline \multirow{3}{*}{$\begin{array}{l}\text { Benefits for well- } \\
\text { being }\end{array}$} & $\mathrm{X} .1 .1$ & 0.829 & Valid \\
\cline { 2 - 4 } & $\mathrm{X} .1 .2$ & 0.856 & Valid \\
\cline { 2 - 4 } & $\mathrm{X} .1 .3$ & 0.862 & Valid \\
\hline \multirow{2}{*}{$\begin{array}{l}\text { Use of storage } \\
\text { service finance }\end{array}$} & $\mathrm{X} .1 .4$ & 0.830 & Valid \\
\cline { 2 - 4 } $\begin{array}{l}\text { Access to financial } \\
\text { financing }\end{array}$ & $\mathrm{X} .1 .5$ & 0.754 & Valid \\
\cline { 2 - 4 } & $\mathrm{X} .1 .7$ & 0.875 & Valid \\
\hline \multirow{3}{*}{$\begin{array}{l}\text { Quality of financial } \\
\text { services }\end{array}$} & $\mathrm{X} .1 .8$ & 0.911 & Valid \\
\cline { 2 - 4 } & $\mathrm{X} .1 .9$ & 0.748 & Valid \\
\cline { 2 - 4 } & $\mathrm{X} .1 .10$ & 0.659 & Invalid \\
\hline
\end{tabular}

Table 3: Loading Factor Value of MSMEs' Performance (Y)

\begin{tabular}{|l|c|c|c|}
\hline Indicator & Item & Loading Factor & Results \\
\hline \multirow{3}{*}{$\begin{array}{l}\text { Workforce } \\
\text { growth }\end{array}$} & Y.1.1 & 0.359 & Invalid \\
\cline { 2 - 4 } & Y.1.2 & 0.773 & Valid \\
\cline { 2 - 4 } & Y.1.3 & 0.748 & Valid \\
\hline \multirow{4}{*}{ Profit growth } & Y.1.4 & 0.803 & Valid \\
\cline { 2 - 4 } & Y.1.5 & 0.640 & Invalid \\
\cline { 2 - 4 } & Y.1.6 & 0.588 & Invalid \\
\hline \multirow{2}{*}{$\begin{array}{l}\text { Market share } \\
\text { growth }\end{array}$} & Y.1.7 & 0.805 & Valid \\
\cline { 2 - 4 } & Y.1.8 & 0.513 & Invalid \\
\hline \multirow{2}{*}{ Sales growth } & Y.1.9 & 0.816 & Valid \\
\cline { 2 - 4 } & Y.1.10 & 0.677 & Invalid \\
\hline
\end{tabular}


Table 4: Loading Factor Value of Financial Intermediation (Z1)

\begin{tabular}{|l|c|c|c|}
\hline Indicator & Item & Loading Factor & Results \\
\hline \multirow{5}{*}{$\begin{array}{l}\text { Market } \\
\text { penetration }\end{array}$} & Z.1.1 & 0.749 & Valid \\
\cline { 2 - 4 } & Z.1.2 & 0.733 & Valid \\
\cline { 2 - 4 } & Z.1.3 & 0.840 & Valid \\
\cline { 2 - 4 } & Z.1.4 & 0.844 & Valid \\
\cline { 2 - 4 } & Z.1.5 & 0.600 & Invalid \\
\cline { 2 - 4 } & Z.1.6 & 0.776 & Valid \\
\hline \multirow{5}{*}{$\begin{array}{l}\text { Service } \\
\text { quality }\end{array}$} & Z.1.7 & 0.513 & Invalid \\
\cline { 2 - 4 } & Z.1.8 & 0.492 & Invalid \\
\cline { 2 - 4 } & Z.1.9 & 0.566 & Invalid \\
\cline { 2 - 4 } & Z.1.10 & 0.815 & Valid \\
\cline { 2 - 4 } & Z.1.11 & 0.804 & Valid \\
\cline { 2 - 4 } & Z.1.12 & 0.638 & Invalid \\
\cline { 2 - 4 } & Z.1.13 & 0.843 & Valid \\
\cline { 2 - 4 } & Z.1.14 & 0.813 & Valid \\
\cline { 2 - 4 } & Z.1.15 & 0.810 & Valid \\
\cline { 2 - 4 } & Z.1.16 & 0.734 & Valid \\
\hline
\end{tabular}

Table 5: Loading Factor Value of Access to Capital (Z2)

\begin{tabular}{|l|c|c|c|}
\hline Indicator & Item & Loading Factor & Results \\
\hline \multirow{4}{*}{$\begin{array}{l}\text { Formal credit } \\
\text { information }\end{array}$} & Z.2.1 & 0.827 & Valid \\
\cline { 2 - 4 } & $\mathrm{Z} .2 .2$ & 0.866 & Valid \\
\cline { 2 - 4 } & $\mathrm{Z} .2 .3$ & 0.867 & Valid \\
\cline { 2 - 4 } & $\mathrm{Z} .2 .4$ & 0.880 & Valid \\
\cline { 2 - 4 } & $\mathrm{Z} .2 .5$ & 0.841 & Valid \\
\hline \multirow{2}{*}{$\begin{array}{l}\text { MSMEs } \\
\text { procedures } \\
\text { for accessing } \\
\text { capital }\end{array}$} & $\mathrm{Z} .2 .6$ & 0.898 & Valid \\
\cline { 2 - 4 } & $\mathrm{Z} .2 .7$ & 0.828 & Valid \\
\cline { 2 - 4 } & $\mathrm{Z} .2 .8$ & 0.846 & Valid \\
\hline
\end{tabular}

\subsubsection{Variable Reliability}

The reliability of a variable can be assessed from the composite reliability and Cronbach's Alpha from the indicator block that measures the variable. The variable is said to be reliable if the composite reliability and Cronbach's Alpha value is above 0.70 . In addition, the variable can be said to be reliable if the AVE value is above 0.5 (see Table 6).

The results of the composite reliability, Cronbach's Alpha and AVE output are presented in Table 6. It can be seen that composite reliability and Cronbachs Alpha value, both for financial inclusion (X), MSMEs' performance (Y), financial intermediation (Z1), and access to capital (Z2) is above 0.7 . In addition, the AVE value of all variables is more than 0.5 . This shows that the variables studied have good reliability. It can be concluded that the variables used in this study are reliable enough for measurement and can be used as variables for future research.

\subsection{Inner Model Test}

\subsubsection{Total Effect}

The total effect is the sum of the direct and indirect effects, while the indirect effect is the multiplication of all direct effects that are passed. The direct and indirect effect is obtained from the Original Sample value or path coefficient value (see Table 7).

\subsection{Structural Model Test}

\subsubsection{Goodness of Fit Model Test}

Structural model test is carried out by looking at the R-square value, which is the goodness of fit model test (see Table 8). The validity of financial intermediation variable can be explained by the variability of financial inclusion variable of $49.5 \%$. The variability of access to capital variable can be explained by the variability of financial inclusion variable of $59 \%$. The variability of MSMEs' performance variable can be explained by the variability of financial inclusion variable of $44.7 \%$.

Table 6: Composite Reliability, Cronbachs Alpha, and AVE Value

\begin{tabular}{|l|c|c|c|c|}
\hline & Composite Reliability & Cronbachs Alpha & AVE & Results \\
\hline Financial Inclusion & 0.950 & 0.939 & 0.707 & Reliable \\
\hline MSMEs Performance & 0.913 & 0.882 & 0.678 & Reliable \\
\hline Financial Intermediation & 0.952 & 0.945 & 0.613 & Reliable \\
\hline Access to Capital & 0.957 & 0.949 & 0.735 & Reliable \\
\hline
\end{tabular}


Table 7: Total Effect

\begin{tabular}{|c|c|c|}
\hline Effect & Path & Total effect \\
\hline \multirow{6}{*}{ Direct effect } & Financial Inclusion -> Financial Intermediation & 0.704 \\
\hline & Financial Inclusion -> Access to Capital & 0.767 \\
\hline & Financial Inclusion -> MSMEs Performance & 0.466 \\
\hline & Financial Intermediation -> MSMEs Performance & 0.668 \\
\hline & Access to Capital -> MSMEs Performance & 0.100 \\
\hline & Financial Intermediation -> Access to Capital & 0.067 \\
\hline
\end{tabular}

Table 8: R-Square

\begin{tabular}{|l|c|}
\hline Variable Relationship & R-Square Value \\
\hline Financial Inclusion -> Financial Intermediation & 0.495 \\
\hline Financial Inclusion -> Access to Capital & 0.590 \\
\hline Financial Inclusion -> MSMEs Performance & 0.447 \\
\hline
\end{tabular}

Table 9: Test Results of Influence between Variables

\begin{tabular}{|c|c|c|c|}
\hline Relationship between Variable & Original Sample & t-statistic & P Value \\
\hline Financial Inclusion -> MSMEs Performance & -0.075 & 0.864 & $0.646^{*}$ \\
\hline Financial Inclusion -> Financial Intermediation & 0.704 & 12.884 & $0.000^{* * *}$ \\
\hline Financial Inclusion -> Access to Capital & 0.719 & 8.761 & $0.000^{* * *}$ \\
\hline Financial Intermediation -> Access to Capital & 0.067 & 0.864 & $0.405^{* *}$ \\
\hline Financial Intermediation -> MSMEs Performance & 0.661 & 4.815 & $0.000^{* * *}$ \\
\hline Access to Capital -> MSMEs Performance & 0.100 & 0.691 & $0.467^{* *}$ \\
\hline
\end{tabular}

Note: *** Significant in $1 \%$ significance level

** Significant in $5 \%$ significance level

* Significant in $10 \%$ significance level

\subsection{2. $T$ Test}

The structural model test aims to determine whether there is an influence between variables, which is carried out using $t$ test. The variable is said to have an influence if $t$ count is greater than $t$ table (1.96). The value of each relationship between the research variables is shown in Table 9:

Based on Table 9, it can be seen that financial inclusion has a significant influence on MSMEs' performance with $10 \%$ significance level, and has a significant influence on financial intermediation with $1 \%$ significance level. In addition, financial inclusion also has a significant influence on access to capital with $1 \%$ significance level. Financial intermediation has a significant influence on MSMEs performance with $1 \%$ significance level. The influence on access to capital on MSMEs' performance is also significant with $5 \%$ significance level. Financial intermediation also has a significant influence on access to capital with $5 \%$ significance level.

\subsection{Mediation Variable Test}

Based on Table 10, it is known that financial inclusion has a significant influence on MSMEs' performance through financial intermediation with $1 \%$ significance level. Financial inclusion also has a significant influence on MSMEs' performance through access to capital with $10 \%$ significance level. Financial inclusion has a significant influence on access to capital through financial intermediation with $5 \%$ significance level. Financial inclusion has a significant influence on MSMEs' performance through financial intermediation and access to capital with $10 \%$ significance level. 
Table 10: Test Results of Mediation Variable

\begin{tabular}{|l|c|c|c|}
\hline Relationship between Variable & Original Sample & t-statistic & P Value \\
\hline Financial Inclusion -> Financial Intermediation -> MSMEs Performance & 0.440 & 4.365 & $0.000^{\text {*** }}$ \\
\hline Financial Inclusion -> Access to Capital -> MSMEs Performance & 0.049 & 0.521 & $0.603^{*}$ \\
\hline Financial Inclusion -> Financial Intermediation -> Access to Capital & 0.047 & 0.817 & $0.414^{* *}$ \\
\hline $\begin{array}{l}\text { Financial Inclusion -> Financial Intermediation -> Access to Capital -> MSMEs } \\
\text { Performance }\end{array}$ & 0.005 & 0.412 & $0.680^{*}$ \\
\hline
\end{tabular}

Note: ${ }^{* * *}$ Significant in $1 \%$ significance level

** Significant in $5 \%$ significance level

* Significant in $10 \%$ significance level

\section{Discussion}

\subsection{The Influence of Financial Inclusion on MSMEs' Performance}

The results of $\mathrm{H} 1$ hypothesis testing regarding the direct influence of financial inclusion on MSMEs performance are accepted with $10 \%$ significance level. These results illustrate that the higher the ability of MSMEs to access financial services, the better MSMEs' performance in Malang City would be. Financial inclusion can directly improve MSMEs' performance in Malang, which means that all efforts to increase access and use of financial services, which increase financial services users welfare, can improve MSMEs' performance. It indicates that financial inclusion will enable MSMEs to access more affordable financial services, so as to improve MSMEs' performance through sufficient funding to finance the company's long-term assets to facilitate business growth. This is reinforced by the results of loading factor, which shows that financial inclusion is reflected in the dimensions of access to financial finance, which include the suitability and benefits of loan products provided by banks. Meanwhile, MSMEs performance is reflected by growth in the main market share, followed by workforce growth, sales growth, and profit growth. The results of this study are in line with several previous studies conducted by Egbetunde (2012); Goodland et al. (2012); Khan (2011); Martinez (2011); Mbotor and Uba (2013); Okafor (2012); Onaolapo (2015); and Yaron et al. (2013). In general, good financial inclusion has high potential to create high financial performance.

\subsection{The Influence of Financial Inclusion on Financial Intermediation}

The results of $\mathrm{H} 2$ hypothesis testing regarding the direct influence of financial inclusion on financial intermediation are accepted with 1\% significance level. These results illustrate that high financial inclusion will also be followed by an increase in the financial intermediation of MSME actors in Malang, and vice versa. The results show that financial inclusion can directly increase financial intermediation at MSMEs in Malang. This means that all efforts to increase access, availability, and benefits of the formal financial system for all economic actors are able to increase market penetration and service quality of financial institutions. In other words, efforts to increase access to financial finance through the ease of terms and conditions regarding the use of loans provided by banks/cooperatives are able to improve the relationship between financial institutions and MSMEs by increasing MSMEs' loyalty and satisfaction.

The results of this study are in line with Fahmy et al. (2016), who stated that financial inclusion can help overcome financial problems. The more bank office networks there are, the more credit will be absorbed in this sector. According to Mishkin (2007), financial intermediation through the opening of many bank branches and the entry of new financial service provider in financial market, can pave the way for the provision of varieties of financial products and services in accordance with MSMEs needs, particularly in providing access to capital. Chandan and Mishra (2010) also argued that the presence of financial institution structures such as offices, branches, and personnel results in increased access to financial services by MSMEs. Good financial inclusion has high potential to create high financial intermediation.

\subsection{The Influence of Financial Intermediation on MSMEs' Performance}

The results of $\mathrm{H} 3$ hypothesis testing regarding the direct influence of financial intermediation on MSMEs' performance are accepted with $1 \%$ significance level. It indicates that financial intermediation can directly influence MSMEs' performance in Malang. Therefore, the banking efforts to increase market penetration and its services to increase MSMEs' satisfaction and loyalty can improve MSMEs' performance through the increase of market share growth, workforce growth, sales growth, and profit growth 
of the MSMEs. The results of this study are in line with the study conducted by Mishkin (2007), Primus (2015), Ahmad and Ali (2015). Good financial intermediation has high potential to create high MSMEs performance.

\subsection{The Influence of Financial Inclusion on Access to Capital}

The results of H4 hypothesis testing show that financial inclusion significantly influences access to capital with $1 \%$ significance level. Financial inclusion can directly increase access to capital of MSMEs in Malang. In other words, all efforts to increase access, availability, and benefit of formal financial system for all economic actors can increase the ease of formal credit procedure and reduce the cost of loans for capital provider institutions that are felt by MSMEs in Malang city. The results of this study show that financial inclusion positively and significantly influences access to capital. This is in line with the previous studies conducted by Okafor (2012), Nurjanah (2017), and Donati (2016). In general, good financial inclusion has high potential to create high access to capital.

\subsection{The Influence of Financial Intermediation on Access to Capital}

The results of H5 hypothesis testing show that financial intermediation significantly influences access to capital with 5\% significance level. It indicates that financial intermediation can increase access to capital. The increase of market penetration and banking services will increase banking efforts to simplify procedures and reduce borrowing costs, so that a good relationship exists between borrowers and those who are given loans. This is because banks have ideas to increase customer satisfaction, have clear market segments, strive to increase customer loyalty, increase the frequency and volume of services, and strive to have product and price advantages over competitors. The results of this study show that financial intermediation positively and significantly influences access to capital in MSME actors in Malang. This is in line with the previous studies carried out by Mishkin (2007), Primus (2015), Ahmad and Ali (2015). In general, good financial intermediation has high potential to create high access to capital.

\subsection{The Influence of Access to Capital on MSMEs' Performance}

The results of H6 hypothesis testing regarding the influence of access to capital on MSMEs' performance are significant with 5\% significance level. Access to capital can directly improve MSMEs' performance in Malang City. This means that the ease of loan procedures and low borrowing costs at capital provider institution can improve MSMEs' performance. MSMEs are satisfied with the process of obtaining loans, the value of loans provided, and the ease of accessing credit from banks, and the interest rates charged by banks that are considered to be lower than other financial institutions.

Access to financing sources is very important for company survival and performance, because finance is the heart of every company. Companies cannot survive without sufficient funds for working capital needs, fixed asset investment, placement of skilled labor, and development of new markets and products (GPFI, 2011). However, in fact, MSMEs' access to capital is still low. The limited public access to financial institutions has an impact on the weak capital of MSMEs, so that MSMEs cannot develop. Primus (2015) emphasized that MSMEs has great potential, thus capital support and guidance are needed to support their business environment. Access to capital and finance are important tools used to pursue growth opportunities for MSMEs' performance (Ahmad $\&$ Arif, 2015). The research results show that access to finance positively and significantly influences MSMEs performance in Malang. This is in accordance with Mishkin (2007), Primus (2015), Ahmad and Ali (2015). In general, good access of finance has high potential to create high MSMEs’ performance.

\subsection{The Mediation Role of Financial Intermediation on the Influence of Financial Inclusion on MSMEs' Performance}

The results of $\mathrm{H} 7$ hypothesis testing regarding the influence of financial inclusion on MSMEs' performance through financial intermediation are significant with $1 \%$ significance level. Financial intermediation is able to mediate the influence of financial inclusion on MSMEs' performance in Malang. This means that all efforts to increase access, availability, and benefit of formal financial system for all economic actors will improve greater MSMEs' performance if it is supported by the increase of financial intermediation. Financial intermediation is realized by expanding banking penetration through opening branches and adding facilities to get closer to customers. Expanding banking market penetration and improving banking services will improve MSMEs' performance in Malang by increasing the capacity of MSMEs' financing from banks. Financial service support that is offered by banks and improved the nutrition of economic actors in Malang city resulting in increased access to finance, increased welfare, and education for MSME actors. In addition, savings products provided by banks are deemed suitable, safe, and in accordance with the MSMEs' needs. The terms and conditions regarding the use of loans provided by banks are profitable and safe for them. 
This creates a relationship between lenders and borrowers so that a common goal is achieved within a certain period.

\subsection{The Mediation Role of Access to Capital on the Influence of Financial Inclusion on MSMEs' Performance}

The results of $\mathrm{H} 8$ hypothesis testing regarding the mediation role of access to finance on the influence of financial inclusion on MSMEs' performance are accepted with $10 \%$ significance level. Access to capital is proved to be able to mediate the influence of financial inclusion on MSMEs' performance in Malang, although it is not as strong as the mediation role of financial intermediation. It implies that all efforts to increase access, availability, and benefit of the formal financial system for MSMEs, which lead to no constraints related to administrative costs or procedures for capital provider institutions that are felt by MSMEs will be able to improve MSMEs' performance. Financial inclusion has provided opportunities for MSMEs in Malang city to obtain funding. Companies find it easy to access credit from banks and more often get loans from banks. MSME actors in Malang felt that interest rates charged by banks are reasonable and very attractive. This has led to an increase in the MSMEs' performance in Malang City.

\subsection{The Mediation Role of Financial Intermediation and Access to Capital on the Influence of Financial Inclusion on MSMEs' Performance}

Financial inclusion also has a significant influence on MSMEs' performance through financial intermediation and access to capital with $10 \%$ significance level. It can be interpreted that all efforts to increase access, availability, and benefits of the formal financial system for MSMEs in Malang have led to a relationship between lenders (banks) and borrowers (MSMEs). Apart from that, low administration costs and easy funding procedures for MSMEs in Malang City will improve MSMEs' performance. Financial inclusion causes banks to have the ideas to increase customer satisfaction through better services, products that meet customer needs, and collaboration with customer community, namely MSMEs in Malang City. This can make MSME players excited to develop businesses to increase business growth.

\section{Conclusion}

Financial inclusion has a direct influence on MSMEs' performance. This shows that the efforts to increase access to financial services, especially access to credit financing for MSMEs, will be able to increase market share, number of workers, sales, as well as profit of the MSMEs. These efforts to improve access to financial services will have a higher impact on MSMEs' performance if it is followed by increased financial intermediation and access to capital.

The results of this study show that increased access to financial services, which is reflected by access to credit financing for MSMEs, will increase banking efforts to increase market penetration by providing service improvements to increase MSMEs' satisfaction and loyalty. Increased banking market penetration will increase access to finance in the form of clear and easy credit procedures, followed by low credit costs, which have greatly helped MSMEs in increasing capital financing in order to increase performance through increasing market share, number of employee, sales, and profits.

The effort to improve access to financial services will have a higher impact on improving MSMEs' performance if increased access to financial services is also followed by increased financial intermediation through increasing banking branches in the regions that will bring access to financial services for MSMEs. Meanwhile, access to capital does not really have great influence on the influence of financial inclusion on MSMEs' performance.

\section{References}

Abdmoulah, W., \& Jelili, R. B. (2013). Access to Finance Thresholds and the Finance-Growth Nexus. Economic Papers: A Journal of Applied Economics and Policy, 32(4), 522-534.

Amidžić, G., Massara, A., \& Mialou, A. (2014). Assessing Countries Financial Inclusion Standing: A New Composite Index. Working Paper No. WP/14/36. Washington, DC: International Monetary Fund.

Bank Indonesia. (2013). National Strategy for Financial Inclusion - Central Bank of the Republic of Indonesia. Jakarta, Indonesia: Bank Indonesia.

Bank Indonesia. (2014). Inclusive Finance Booklet. Jakarta, Indonesia: Bank Indonesia.

Beck, T., Demirguc-Kunt, A. and Maksimovic, V. (2004) Financial and legal constraints to growth: Does firm size matter? Journal of Finance, 60(1), 137-177.

Calantone, R. J., Cavusgil, S. T., \& Zhao, Y. (2002). Learning orientation, firm innovation capability, and firm performance. Industrial Marketing Management, 31(6), 515-524. doi: 10.1016/S0019-8501(01)00203-6.

Chakravarty, S. R., \& Pal, R. (2013). Financial inclusion in India: An axiomatic approach. Journal of Policy Modeling, 35(5), 813-837. doi: 10.1016/j.jpolmod.2012.12.007.

Chauvet, L., \& Jacolin, L. (2017). Financial Inclusion, Bank Concentration, and Firm Performance. World Development, 97, 1-13. 
Demirguc-Kunt, A., \& Klapper, L. (2012). Measuring Financial Inclusion: The Global Findex Measuring Financial Inclusion The Global Findex Database. doi: 10.1596/1813-9450-6025.

Donati, C. (2016). Firm Growth and Liquidity Constraints: Evidence from the Manufacturing and Service Sectors in Italy. Applied Economics, 48(20), 1881-1892.

Egbetunde, T. (2012). Bank credits and rural development in Nigeria (1982-2009). International Journal of Finance and Accounting, 1(3), 45-52.

Ejiofor, E., Camillus, Ok. N., \& Ubogu, F. E. (2020). Effects Of Financial Inclusion On The Growth Of Cottage Firms In Nigeria. American Research Journal of Humanities dan Social Science, 3(1), 6-14.

Ergungor, E. . (2010). Bank branch presence and access to credit in low to moderate income neighbourhood. Journal of Money, Credit and Banking, 42(7), 1321-1349.

Fafchamps, M., \& Schündeln, M. (2013). Local Financial Development and Firm Performance: Evidence from Morocco. Journal of Development Economics, 103, 15-28.

Fahmy, O. M., Rustam, M., \& Asmayadi, E. (2016). The Effect of Inclusive Finance on Loans Disbursed in the Micro, Small and Medium Enterprises Sector in Indonesia. Jurnal Ekonomi dan Bisnis, Universitas Tanjungpura, 2, 118-135. [Indonesian]

Goldsmith, R. W. (1969) Financial Structure and Development. New Haven, CT: Yale University Press.

Haltiwanger, J., Jarmin, R. S., \& Miranda, J. (2013). Who creates jobs? Small versus large versus young. Review of Economics and Statistics, 95(2), 347-361. https://doi.org/10.1162/ REST_a_00288

Hannig, A., \& Jansen, S. (2010). Financial Inclusion and Financial Stability: Current Policy Issues Asian Development Bank Institute. Retrieved from: www.adbi.org (Accessed: 1 January 2020).

Herispon. (2017). Financial Inclusion, and the Role of the NonBank Financial Industry in the Development of Micro, Small and Medium Enterprises. Jurnal Eko dan Bisnis, 8(1), 70-84. [Indonesian]

Joni, J., Ahmed, K., \& Hamilton, J. (2019). Politically connected boards, family business groups and firm performance: evidence from Indonesia. Journal of Accounting and Organizational Change, 16(1), 93-121.

Kempson, E. (2006). Policy Level Response to Financial Exclusion in Developed Economies: Lessons for Developing Countries. In: Access to Finance conference: Building Inclusive Financial Systems. Washington, DC: The World Bank.

Kendall, J., Ponce, A., \& Mylenko, N. (2010). Measuring Financial Access Around The World. The World Bank Policy Research Working Papers. doi: 10.1596/1813-9450-5253.

Khan, S. H. R. (2011). Financial inclusion and financial stability: are they two sides of the same coin ? Indian Bankers Association dan Indian Overseas Bank, Chennai, (November), 1-12.
King, A. W., \& Zeithaml, C. P. (2001). Competencies and firm performance: examining the causal ambiguity paradox, Strategic Management Journal, 22(1), 75-99. doi: 10.1002/1097-0266(200101)22:1<75::AID-SMJ145>3.0.CO;2-I.

Lee, C.-C., Wang, C.-W., \& Ho, S.-J. (2019). Financial Inclusion, Financial Innovation, and Firms Sales Growth, International Review of Economics and Finance, 66(C), 189-205.

Martinez, M. V. (2011). The Political Economy of Increased Financial Access. Georgetown University.

Mathews, K., \& Thompson, J. (2008). The Economics of Banking. Chicheste, UK: Wiley-Interscience.

McKinnon, R. I. (1973). Money and capital in economic development. Washington, DC: Brookings Institution.

Mehrotra, A. N. et al. (2015). Financial inclusion - issues for central banks, BIS Quarterly Review. Bank for International Settlements.

Merton, R., \& Bodie, Z. (2004). Design of Financial Systems: Towards A Synthesis of Function and Structure. Journal of Investment Management, 3(1), 1-23.

Morgan, P. J., \& Pontines, V. (2014). Financial Stability and Financial Inclusion, ADBI Working Paper Series 488. Tokyo, Japan: East Asian Bureau of Economic Research.

Neaime, S., \& Gaysset, I. (2018) Financial inclusion and stability in MENA: Evidence from poverty and inequality. Finance Research Letters, 24, 230-237. doi: 10.1016/J. FRL.2017.09.007.

Nissanke, M., \& Stein, H. (2003) Financial Globalization and Economic Development: Toward an Institutional Foundation. Eastern Economic Review, 29(2).

Nurjannah, L. (2017). The Role of Financial Inclusion in the Development of MSMEs in Yogyakarta. Yogyakarta, Indonesia. [Indonesian]

Okafor, F. O. (2012). Financial Inclusion: An Instrument for Economic Growth and Balanced Development in Rural Areas. Journal of the Chartered Institute of Bankers of Nigeria, 6(8), $38-45$.

Onaolapo, A. R. (2015). Effects of financial inclusion on the economic growth of Nigeria. International Journal of Business and Management Review, 3(8), 11-28.

Phornlaphatrachakorn, K., \& Na-Kalasindhu, K. (2020). Strategic Management Accounting and Firm Performance: Evidence from Finance Business in Thailand. Journal of Asian Finance, Economics and Business, 7(8), 309-321. https://doi. org/10.13106/jafeb.2020.vol7.no8.309

Prasad, E. S. (2010). Financial Sector Regulation and Reforms in Emerging Markets: An Overview. NBER Working Paper No. 16428. Available at: http://www.nber.org/papers/w16428 (Accessed: 1 January 2020).

Rau, N. (2004). Financial Intermediation and Access to Finance in African Countries South of the Sahara. Somerset West, South Africa. 
Rivai, V., Veithzal, A. P., \& Idroes, F. N. (2007). Bank and Financial Institution Management. Jakarta, Indonesia: Raja Grafindo Persada.

Rokhayati, I. (2015). Performance Measurement in Micro, Small and Medium Enterprises (MSMEs): A Literature Review. Purwokerto, Indonesia: UNWIKU.

Sarma, M. (2012). Index of Financial Inclusion - A measure of financial sector inclusiveness. No. 07/2012. Available at: https:// finance-and-trade.htw-berlin.de/fileadmin/HTW/Forschung/ Money_Finance_Trade_Development/working_paper_series/ wp_07_2012_Sarma_Index-of-Financial-Inclusion.pdf.

Shaw, E. (1973). Financial Deepening in Economic Development. New York, NY: Oxford University Press.

Tika, M. P. (2012). Organizational Culture and Improving Company Performance. Jakarta, Indonesia: Bumi Aksara.
Word Bank. (2014). Doing Business 2014: Understanding Regulations for Small and Medium-Size Enterprises. Washington, DC: The World Bank.

Xuan, V. N. (2020). Determinants of Investment Capital Size: A Case of Small and Medium-Sized Enterprises in Vietnam. Journal of Asian Finance, Economics and Business, 7(6), 19-27. https://doi.org/10.13106/jafeb.2020.vol7.no6.019

Yaron, J., Benjamin, M. P., \& Piprek, G. L. (2013). Rural Finance: Issue, Design, and Best Prctices. Washington, DC: The World Bank.

Yudaruddin, R. (2020). Determinants of Micro-, Small- and Medium-Sized Enterprise Loans by Commercial Banks in Indonesia. Journal of Asian Finance, Economics and Business, 7(9) 19-30. https://doi.org/10.13106/jafeb.2020.vol7.no9.019

Zain, N. H. (2010). Relationship between Islamic Banking and Micro, Small and Medium Enterprises (MSMEs) in Indonesia. Dikta Ekonomi, 7(2), 146-158. 